\title{
Studying the practices of implementing a multilingual model of multicultural education in the Russian Federation
}

\author{
Raisa M. Iksanova ${ }^{1}$, Zarima R. Kireeva ${ }^{1}$, Eduard I. Sattarov ${ }^{1}$, Salavat T. Sagitov $\square{ }^{1}$ \\ ${ }^{1}$ Bashkir State Pedagogical University named after M. Akmulla, Ufa, Russian Federation
}

\begin{abstract}
Introduction. The article discusses the practices of implementing a multilingual model of multicultural education in the Russian Federation. The Russian Federation is a multinational and linguistically diverse country. The official language of the country is Russian; 37 state languages are spoken in the republics of the Russian Federation; more than 15 languages have an official status. For a number of regions of the country, the model of multilingual learning is extremely relevant.

The purpose of the article is to study the practices of implementing a multilingual model of multicultural education in the territory of the Russian Federation and to conduct their comparative analysis.

Materials and Methods. Within the framework of the study, the analysis of legislative documents regulating the processes of multicultural and multilingual education in the Republic of North OssetiaAlania, Kabardino-Balkar Republic, Chechen Republic, Republic of Sakha (Yakutia), Republic of Tatarstan, Chuvash Republic, Republic of Bashkortostan (state programs, concepts, regulations, etc.) was carried out. Data gathering included round-table discussions and interviews with the representatives of academic and teaching communities of the regions; analyses of curricula, syllabi and teaching materials on language disciplines; lesson observations; questionnaires and language assessment of primary (4th grade) and secondary schoolchildren (8th grade) in foreign and native languages; analysis of academic performance and attainment (e.g. the results of the All-Russian Olympiad of schoolchildren in Russian and Foreign Languages, national assessment, state final certification, and final national examinations).

Results. The research team of Bashkir State Pedagogical University named after M. Akmulla, in accordance with the state task in the field of science of the Ministry of Education of the Russian Federation, has been implementing a research investigation 'Comparative analysis of the practices of
\end{abstract}

\section{Acknowledgments}

The study was financially supported by the Ministry of Education of the Russian Federation. Project No. 073-032021-015/2, Dated 07/21/2021 (within the framework of the state task for the implementation of research work "Comparative analysis of the practices of implementing a multilingual model of multicultural education").

\section{For citation}

Iksanova R. M., Kireeva Z. R., Sattarov E. I., Sagitov S. T. Studying the practices of implementing a multilingual model of multicultural education in the Russian Federation. Science for Education Today, 2022, vol. 12 (1), pp. 127-149. DOI: http://dx.doi.org/10.15293/2658-6762.2201.06

曰@ Corresponding Author: Salavat T. Sagitov, salavatst@list.ru

(C) Raisa M. Iksanova, Zarima R. Kireeva, Eduard I. Sattarov, Salavat T. Sagitov, 2022 
implementing a multilingual model of multicultural education (with the main focus on the Republics of Bashkortostan, Tatarstan, North Ossetia-Alania, Sakha (Yakutia), etc.)' since 2021.

The authors have determined the main types of models of multilingual education implemented in the studied regions. In particular, the models presented in the Republic of North Ossetia-Alania, the Republic of Tatarstan and the Republic of Sakha (Yakutia) are reported to be the most developed as they have been implemented for several years. The findings in this study contribute to a greater understanding of the specifics of multilingual education in Russia and the study makes a theoretical contribution to multilingual education in general.

Conclusions. The article concludes that currently there is no a single coordinated model for multilingual education in Russian schools. The development of a multilingual model of multicultural education is primarily aimed at preserving and further developing the native languages in the subjects of the Russian Federation, remaining one of the most important tasks not only in terms of solving narrow ethno-cultural problems, but also in the context of preserving the natural multicultural basis of the multinational Russian state.

\section{Keywords}

Multilingual education; Multilingual model; Practice of implementing a multilingual model; Multicultural environment; Comparative analysis of practices of implementing a multilingual model; Education system; Native language.

\section{Introduction}

One of the most important and integral elements of culture is language. There is not a single human community, not a single culture that would exist without a language [1]. At the same time, language, by its very nature, cannot exist without culture. Language is currently the main means of preserving, developing and transmitting cultural values, both within one society and between different social groups and communities in each specific period of time, as well as in historical perspective and retrospective, and the importance of language as one of the elements of culture is difficult to underestimate both in the development of any social community and in the formation of Russian statehood and national selfidentity [2]. A decrease in the presence of language in various spheres of human activity can lead not only to a reduction in its use, but also to a further rejection of its use [3]. Given that language is one of the most important elements of an individual's self-determination on a national basis, it can be argued that the disappearance of a language entails the disappearance of an ethnic group as such. That is why the issues of language preservation today, in the period of globalization and intensive digitalization, acquire a special connotation, posing questions of determining the vector of further development to different social communities, especially in such a multinational country as the Russian Federation.

According to the classification adopted by $\mathrm{UNESCO}^{1}$, all languages, depending on a number of factors (the absolute number of native speakers, the transfer of the language to the next generation, the scope of language use, administrative use of the language, the degree of its documentation, etc.) are divided into six categories:

$$
\begin{aligned}
& \text { - safe; } \\
& \text { - vulnerable; }
\end{aligned}
$$

\footnotetext{
${ }^{1}$ The UNESCO Atlas of the world's languages in danger: context and process / University of Cambridge Museum of Archaeology and Anthropology, 2012.
} 
- definitely endangered;

- severely endangered;

- critically endangered;

- extinct.

UNESCO has developed a comprehensive methodology to assess the state of linguistic diversity in the world as part of the Organization's commitment and contribution to the promotion of linguistic diversity and multilingualism. Thanks to the contribution of UNESCO member States, researchers, experts and other stakeholders to the Global Survey of Languages launched in 2018 by the UNESCO Institute of Statistics, the development of the World Atlas of Languages is entering its final phase and is to be presented at the $41 \mathrm{st}$ session of the UNESCO General Conference in November $2021^{2}$.

In total, the UNESCO Atlas for 2020, out of more than 6 thousand languages existing in the world, recognizes 2.5 thousand as endangered ${ }^{3}$. Also, according to the expert assessment of the Institute of Linguistics of the Russian Academy of Sciences, there are 151 languages in Russia, of which 18 are on the verge of extinction ${ }^{4}$. At the same time, 14 languages disappeared on the territory of the Russian Federation in the XXXXI centuries, half of which did so in the postSoviet period. Of the remaining languages of Russia, according to the Atlas of Endangered Languages of the World, published by UNESCO in 2020, 136 languages of the peoples and nationalities of Russia are in varying degrees under threat: the state of 20 languages (including Bashkir, Kabardino-Circassian, Chechen, Yakut) is of concern; 49 (including Chuvash, Udmurt, Kalmyk) are endangered; 20 (including Karelian, Chukchi) are in serious danger, 22 languages are in critical condition, and 20 languages have already been recognized as extinct.

Currently, the main feature is that the changes that have occurred in the country over the past 25-30 years have affected not only the country's economy or its political system - the country's population, value orientations and many other things have changed. For the most part, the changes affected young people who have their own attitudes, but have no physical connection with the Soviet period and are not focused on the values inherent in the youth of that time.

To become a full-fledged subject of the social structure, an individual must undergo socialization, master not only knowledge, skills and abilities to perform appropriate professional and other role functions, but also integrate into the system of socio-cultural values, moral norms and ideals, which in turn are in the process of constant change.

It is worth nothing that there was no scientific literature on the comparative analysis of implementation practices and the study of polylingual models of multicultural education in the Russian Federation.

However, in recent years, interest in the study of multilingual learning through the prism of various aspects has been increasing. However, in recent years, interest in the study of polylingual

${ }^{3}$ UNESCO Atlas of the World's Languages in Danger. URL: http://www.unesco.org/new/en/culture/themes/endangered-languages/atlas-of-languages-in-danger/ Accessed: $30^{\text {th }}$ November 2021.

4 Federal Agency for Nationalities. URL: https://fadn.gov.ru/system/attachments/attaches/000/029/833/original/aakibrik_ashl_dialforum2018.ppt?1542391737 Accessed: 22nd April 2019. 
(multilingual) education has been increasing [4; 5; 6]. This is due to a number of reasons.

Thus, the authors indicate that one of the main reasons is the training of personnel for the implementation of multilingual education, insufficient training of teachers to work effectively with multilingual students [7].

"The intensification of global mobility has increased interest in ethnolinguistic diversity and multilingualism in education and society. Interdisciplinary research approaches to multilingual education combine modern interdisciplinary perspectives in the field of multilingual and a second language education for the study of research and teaching of languages in particular countries" [8].

Also, a number of authors point to an important aspect - the participation of parents in the language development of their children [9].

The problems of multilingual education are also studied in the context of social justice ${ }^{5}$, and the practice of multilingual literacy is considered as a springboard for the development of learning opportunities and identity formation [10-12].

The problem of polylingual education is relevant for a number of countries, for example, a large-scale survey of 155 schools was conducted in Hong Kong. In-depth case studies were conducted in 3 selected schools, revealing the views on trilingual education of all stakeholders: school principals, group chairmen, subject teachers, students and parents. The research results indicate that the implementation of trilingual education varies significantly from school to school, as well as the effectiveness of the models of trilingual education used $[13 ; 14]$.

The features of polylingual learning are studied in the field of preschool education from a socio-linguistic point of view. The main attention is paid to preschool polylingual education, modern prospects of early polylingual education are investigated in the light of the threefold theoretical basis of interaction between preschool institutions, teachers and parents. For example, the authors propose the following theoretical concept which includes: the ecology of language learning, educational partnership in the interests of bilingualism, the concept of participation in early language development and education, a context conducive to language, and strategies promoting language development. Preschool bilingual education is considered as embedded in specific socio-cultural contexts, on the one hand, and its universal features are highlighted, on the other [15].

Polylingual education considers the possibility of preserving minority languages, the history of society, culture and customs [16].

The formation of motivation and identity of students in the process of learning and using several languages is considered as one of the problems of polylingual education. Based on the latest theoretical developments concerning the motivation and identity of students in researches related to the study of languages, scientists reveal the motivations of students that underlie their decisions about learning several languages. Through empirical research, the authors propose conceptual interpretations of emerging concepts, such as the dual motivation system, motivation dynamics, episodes of motivational transformation and hierarchies of identities $[17 ; 18]$.

Both Sweden and Finland have education systems that promote equality and equity. However, the social and political changes associated with increased immigration have

\footnotetext{
${ }^{5}$ Conteh J. Researching education for social justice in multilingual settings: ethnographic principles in qualitative research, 2017. $280 \mathrm{p}$.
} 
created new challenges in efforts to support linguistic diversity. The authors of the article study how multilingualism is represented in national compulsory school curricula in two contexts, using the framework of language orientation: language as a problem, a right or a resource. The analysis reveals differences. In Finland, there is a clear discussion about multilingual education with the aim of integrating multilingual aspects into the entire curriculum. However, in Sweden, the discourse is less explicit; and multilingualism as a concept is limited to minority language learners. The consideration of language orientations in two curricula makes it possible to understand the spaces for multilingual education, which are key to the capabilities of teachers to promote both linguistic diversity and social justice in the schools of modern global societies $[19 ; 20]$.

Professor Marianne Visser studies linguistic diversity in Africa, considering it an advantage rather than a complicating factor. "Multilingualism is undoubtedly an advantage. With that said, multilingual education is a really complex undertaking. In particular, the implementation of appropriate educational opportunities is a difficult task. In this regard, the goal is to emphasize the need for systematic cost management of multilingual education and to present the idea of cost optimization as an additional way to improve the practice of multilingual education" [21].

These circumstances, conditioned by the global trend towards integration in all spheres of life, as well as the diversity and multiculturalism of the Russian society, determine great increase of the role and relevance of the realization of the polylingual education concept. Before proceeding to further analysis, we note that in our research by polylingual education we mean a system of education and upbringing that promotes the general cultural and linguistic development of students, which implies a simultaneous use of the Russian, native and foreign languages in the educational process, including extracurricular time. It should also be noted that within the framework of our research, we adhere to the point of view that the terms "polylingual education" and "a polylingual model of multicultural education" are mutually applicable, since all the regions under consideration are multicultural, and the formation of language competence proceeds not only in terms of teaching a particular language, but also through the integration of interdisciplinary knowledge: culture, history, psychology of peoples, etc., covering extracurricular time. By the way, this is what, in our opinion, distinguishes polylingual education from bilingual or multilingual education: the essence of the polylingual education system is that, along with the native language, both Russian and a foreign one are used both as a means of teaching and as a means of multicultural education. Whereas in bilingual or multilingual schools, a language is only the subject of study [22-24].

We would like to note that the issues of polylingual education are relevant for all the regions and territorial communities of our country: republics, territories and regions; for megacities and large cities, for small towns and rural settlements, etc. At the same time, the formation of educational policy does not depend on the circumstances under which the polyethnicity of the population has developed. So, in some territories the multinational population was formed in the XX century (for example, Moscow and the Tyumen region) as a result of migration processes caused by economic aspects of development, whereas in others - its formation took place over a long period of time and today is interpreted as "historically formed" (for example, national republics). At the same time, the 
organization of polylingual education in each region of the country has its own peculiarities, depending on a number of reasons.

In particular, the defining aspect is the national composition of the federal subject: while only two state languages (Russian and Tatar) officially function in the Republic of Tatarstan, in Dagestan, with its ethnic diversity, according to Article 11 of the Constitution of the Republic, the state languages are Russian and the languages of the peoples of Dagestan, among which Avar, Agul, Azerbaijani, Darginsky, Kumyk, Lak, Lezginsky, Nogai, Rutul, Tabasaran, Tat, Tsakhur and Chechen languages have their written form and bare an official status. In addition to the absolute number of nationalities living in the regions, their percentage ratio also matters: while being the third in number in the population of the Kabardino-Balkarian Republic, the Balkars make up slightly less than $10 \%$ of the population of the region, the Tatars, who are also the third largest in the Chuvash Republic make up a little more than $2.8 \%$. The number of representatives of the Russian nationality is also different in the regions of the country: while in Bashkortostan the number of Russians is $40 \%$ (this is the 1 st place in the region among ethnic groups), in the Chechen Republic it is $2 \%$ (the 2 nd place in the region). Of course, the model of polylingual education is also significantly influenced by the territory of the region: compare, for example, huge Yakutia (more than 3 million square kilometers) exceeding Argentina in its territory - the eighth state in the world by area, and North OssetiaAlania, which occupies the 80th place in the Russian Federation by area (7987 square kilometers). At the same time, in the Republic

\footnotetext{
${ }^{6}$ Sagitov S. T. Socio-professional status as a criterion for the classification of social actors. Social consequences of the pandemic: myths and reality. Aitov readings: collec-

of Sakha, the population density is 0.32 people/sq.km, whereas in the Republic of North Ossetia-Alania - 86.78 people/sq. km.

Undoubtedly, the religious component of the region, as well as the belonging of the language to a particular family or group of languages, have a great influence on the development of languages. For example, the spread of Islam led to the inclusion of many borrowings from Arabic into the lexical composition of the languages of Muslim peoples and at the same time caused the consolidation of these languages as the main means of communication between their native speakers.

We can name a number of factors that affect the education system of a particular region of Russia as a whole: these are the infrastructure of social institutions of education and science, culture and religion, the level of urbanization and development of the means of production of the region, etc. In addition, both education and culture, as social institutions, have their own laws of self-development, depending, among other things, on a certain historical situation, and on the development level of the society as a whole, as well as on the level of management culture ${ }^{6}$. Naturally, all this leaves an imprint on the organization of the system of polylingual education [25].

The article discusses the practices of implementing a multilingual model of multicultural education in the Russian Federation. The Russian Federation is a multinational and linguistically diverse country. The official language of the country is Russian; 37 state languages are spoken in the republics of the Russian Federation; more than 15 languages have an official status. For a number of regions of the

tion of materials of the international scientific and practical conference. Ufa, 2021, pp. 22-27. (In Russian) URL: https://elibrary.ru/item.asp?id=45600865\& 
country, the model of multilingual learning is extremely relevant.

The purpose of the article is to study the practices of implementing a multilingual model of multicultural education in the territory of the Russian Federation and to conduct their comparative analysis.

\section{Methods}

In order to study the practices of implementing a polylingual model of multicultural education on the territory of the Russian Federation, to conduct their comparative analysis and develop methodological recommendations for the organization of multicultural education, in 2021, a team of researchers of Bashkir State Pedagogical University named after M. Akmulla, under the guidance of Candidate of Sociological Sciences S. T. Sagitov, started the research work "Comparative analysis of the practices of implementing a polylingual model of multicultural education (on the example of the Republics of Bashkortostan, Tatarstan, North Ossetia-Alania, Sakha (Yakutia), etc.)" in accordance with the state task in the field of science of the Ministry of Education of the Russian Federation.

The object of the study is the polylingual models of multicultural education implemented in secondary educational institutions of seven regions of the Russian Federation: the Republic of Bashkortostan, the Kabardino-Balkar Republic, the Republic of Sakha (Yakutia), the Republic of North Ossetia-Alania, the Republic of Tatarstan, the Chechen Republic, the Chuvash Republic.
The study involves several stages, planned for 2021-2023.

As is known, when studying social phenomena, sociologists tend to choose a research strategy that contributes to a more complete disclosure of the social nature of the phenomenon being studied. In this case, we mean an integrative research strategy that combines qualitative and quantitative research methods. Using only one strategy can lead to "one-sidedness" of the information received, since “... any methodological point of view is partial, incomplete. The polyphony of representations is necessary...."7.

To obtain information about the problem under study, a quantitative methodology of sociological research was chosen.

As the main method of data collection, selfcompletion questionnaires at the place of study were used. The method of continuous questioning of the 4th and 8th grade students in schools, where the model of polylingual learning is implemented, was used.

\section{Results}

Preliminary results of a survey of students of multilingual schools showed the importance of learning their native language. Among the main reasons were indicated: to speak freely with representatives of their ethnic group (more than a third of respondents), the language is an integral part of the history and culture of the ethnic group (less than $30 \%$ ) and to preserve their language $(14.0 \%)$. The full list of responses is given in the table.

\footnotetext{
7 Yarskaya-Smirnova E. R. Sociocultural analysis of atypicity. Saratov, 1997. p. 94. (In Russian) 
Distribution of answers to the question:

"Why do you think it is necessary to study your native (national language)?"

\begin{tabular}{|l|c|}
\hline \multicolumn{1}{|c|}{ Answer options (categorized) } & $\begin{array}{c}\text { Percentage of respondent (in } \\
\text { \%) }\end{array}$ \\
\hline To talk freely with representatives of their ethnic group & 31,9 \\
\hline Language is an integral part of the history and culture of the ethnos & 28,6 \\
\hline To preserve the ethnic group and its culture & 7,9 \\
\hline To preserve one's native language & 14,0 \\
\hline For general development / self-development & 6,1 \\
\hline All representatives of the ethnic group should know the language & 8,5 \\
\hline Other & 7,2 \\
\hline
\end{tabular}

Note: The students' answers to the open question "Why do you think it is necessary to study the native (national) language?" were grouped into several categories for ease of processing and use in data analysis.

During the survey, students were asked a number of open questions about their attitude to the need to learn their native language. As examples, we can cite some of the most striking statements of the students:

"It is very important to know your traditions and cultures in order to be a true representative of your nationality" (a student from the Republic of Sakha (Yakutia), 14 years old); “... if you do not know your native language, then I have no right to call myself a Kabardian. And I will not be able to explain to my child what needs to be studied ..." (a student from the Kabardino-Balkarian Republic, 14 years old); “...the native language is the heritage of the people, it keeps all the history we have passed" (a student from the Chechen Republic, 14 years old).

Preliminary results of the survey show that among children in the regions under study the native language tends to be used in everyday communication. Thus, over $59 \%$ of the surveyed students claim that they speak their native language in the family, communicating with parents and relatives. At the same time, children more often refer to their native (national) language speaking with their parents rather than with their friends (peers). It should be noted that the number of questionnaires in the given regions was equal, which does not violate the principle of a pilot research.

The research program implies three stages by year:

Stage I - 2021 - conducting a pilot study;

Stage II - 2022 - research of polylingual education implemented in preschool educational institutions; focus group interviews;

Stage III - 2023 - research of multilingual education in organizations of primary and basic general education; expert semi-formalized interviews.

Conducting a pilot study on this problem in 2021 was due to the need to collect statistical information, verify the validity of the tasks and hypotheses put forward, identify individual characteristics of the object in order to determine the most stable ones for their further in-depth development.

A secondary analysis of sociological research data allows us to supplement the information collected during the study, confirm or refute the hypotheses of the study, and consider the problems under study in a more versatile way. 
In order to implement the pilot study, diagnostic materials were developed that allowed for comparable data collection in 7 regions of the country.

In 2021, the pilot study was conducted in a mixed format, the following methods being used:

- content analysis of documentation regulating the educational process in the regions;

- collection and analysis of statistical data regarding the assessment of institutional support for the development of polylingual and multicultural education in 7 studied subjects of Russia (state programs, concepts, regulations, etc.);

- analysis of materials of educational and methodological support of polylingual education in organizations of primary and basic general education;

- analysis of the results of students' achievements, in particular, the results of the AllRussian Olympiad of Schoolchildren in Russian and Foreign Languages, All-Russian testing works, state final certification;

- a survey of experts, represented by teachers of general education institutions implementing language disciplines (people);

- testing of 1000 students in the $4^{\text {th }}$ and the $8^{\text {th }}$ grades of general education institutions on the quality of coping with the curricula in native and foreign languages (tests of levels A1 and A2 in accordance with the Common European Framework of Reference for Languages).

It should be noted that of the 7 regions studied, three: The Chechen Republic, the Republic of North Ossetia-Alania, the Republic of Tatarstan, back in 2008, took part in the implementation of a Comprehensive Program for the development of multicultural education, developed on the basis of a conceptual idea of ways to modernize Russian education. According to this Program, a full-fledged multicultural education «forms the content of education and upbringing within the framework of a single state standard in accordance with the construction of Russian identity, while the ethno-cultural heritage and national cultures of the peoples of Russia are broadcast in a broad all-Russian and world cultural and civilizational context according to the general formula "a region - Russia - the world". It is this triad ("a region - Russia - the world") in its various variations that determines the models of polylingual education.

The analysis of the results of the pilot studies allows us to talk about three models currently used in polylingual education in the studied regions. All the three models are built from the methodological point of view - on the implementation of the Federal State Educational Standard of primary and basic general education (the level of secondary general education in the institutions of the analyzed regions is not represented), from the ideological and content viewpoint - on the formation of an all-Russian civic identity that has integrated national cultures of the peoples of Russia, and is an integral part of the world culture. It is worth noting that any model does not involve the organization of different separate components in the context of "region - country", but, on the contrary, ensures the inclusion of a regional educational content into the federal component, which ensures selfidentification of students both at the regionalterritorial and national levels.

In general, the choice of a particular model by educational institutions is determined by two factors:

1. The level of institutional support of regional authorities;

2. The degree of proficiency of students in their native and Russian languages.

The analysis of legislation and regulatory legal acts of the 7 above-mentioned subjects of the Russian Federation suggests that support in the development of Russian, native languages and languages of other 
peoples living in the republics is generally provided. All seven subjects have adopted laws "On education", as well as regional state programs for the development of education, which give place to the development of language education.

In 6 of the 7 regions under consideration, regional laws on the languages of the peoples of the corresponding region have been adopted, which reflect the state languages, official languages (for example, in the Republic of Sakha, where, along with 2 state languages (Russian, Sakha), 5 official languages are established) and the languages of the peoples living in the designated subject of the Russian Federation. The only exception is the Republic of North Ossetia Alania, where, with a sufficiently developed regulatory framework in the field of language policy and a clear consolidation of the state languages (Ossetian and Russian) in the Constitution of the Republic, there is no regional law on languages, due to ongoing discussions about the status of the Digor variant of the Ossetian language.

It is noteworthy that in all the three republics of the North Caucasus there are no existing state programs for the preservation, study and development of the languages of the region recognized as state ones. At the same time, in the 90 s and early 2000s, similar regulations were in force on the territory of the Chechen and Kabardino-Balkarian republics. In the analyzed regions of the Ural-Volga region and in the Republic of Sakha (Yakutia), there do exist programs for the development of the state languages of the republics and the languages of the peoples living in the corresponding region.

As for the very concept of "polylingual education" and related by-law, regulatory legal acts, as officially approved by the executive authority, the concept of multilingual education has been adopted in the republics of Bashkortostan, Tatarstan and the Chechen
Republic (in the latter it is formulated as the concept of multicultural education). In the Chuvash Republic, the processes in the field of education are determined by the program document "Strategies for the development of education in the Chuvash Republic until 2040" which uses the term "polylingualism", but its content is narrowed by the need to master a foreign language. In particular, the above Strategy indicates that "the development of polylinguism and the formation of a person who speaks several languages are among the most important tasks of modern school education. The formation of an open democratic and civil society, foreign economic relations with the countries of the world necessitate the development of foreign languages". There are no officially approved concepts at the state level in the KabardinoBalkarian Republic, in the republics of Sakha (Yakutia) and North Ossetia-Alania. At the same time, there is a project of multilingual education developed by the Yakut Pedagogical College named after S. F. Gogolev "Children of the Arctic: polylingual education", in accordance with which the "International Arctic School" started its work in 2020-2021 academic year.

In the Republic of North Ossetia-Alania, the Concept of the development of polylingual education was developed by the staff of the UNESCO Department of Polylingual and Multicultural Education. In this subject of the Russian Federation, the work on the concept of polylingual education began in 2005. The polylingual approach is understood by the developers as the integration of the diversity of cultures and languages that create an educational environment, ensuring the formation of a scientific and cultural picture of the world for the future generation, starting from preschool age. The conceptual principle (triad) "Ossetia-Russiathe World", which is the basis of the polylingual model of multicultural education, corresponds to 
the natural cognitive needs of students and allows them to realize themselves as citizens of the republic, Russia and the world, with the Ossetian culture fitting into the global cultural space as its harmonious part (T. T. Kambolov). In North Ossetia, educational and methodological kits have been published in many subjects in accordance with the theoretical provisions of the Concept of the Development of Polylingual Education, completed lines of textbooks have been developed and published, as well as bilingual dictionaries in many fields of sciences (for example, V. I. Abaev Ossetian-Russian Dictionary; L. B. Gatsalova, L. K. Parsieva Ossetian-Russian, RussianOssetian Dictionary; A. B. Skodtaev RussianOssetian, Ossetian-Russian school Explanatory Dictionary of Mathematical Terms, etc. ${ }^{8}$. The lines of textbooks on the Ossetian language (for preschool institutions and for grades 1-11) are designed in two versions: for those who speak and those who do not speak the Ossetian language. Separate lines of textbooks on the native language for the Iron and Digor dialects have been published. These textbooks have passed regional pedagogical, scientific, and public expertise.

At the same time, the analysis showed that the development potential is far from being exhausted, it is necessary to promote the search for ways of further development, to point out certain shortcomings in programs and teaching kits. For example, in programs in philological disciplines realized in Ossetia, there is a certain degree of non-synchronous study of topics in the Ossetian and Russian languages. In our work, we proceed from the fact that the Concept is not only a theoretical document - in accordance with it, training is conducted in a number of schools, and

\footnotetext{
${ }^{8}$ Abaev V. I. Russian-Ossetian Dictionary. Moscow: "Soviet Encyclopedia", 1970. 586 p. (In Russian);

Gatsalova L. B., Parsieva L. K. The Great Russian-Ossetian Dictionary. Vladikavkaz, IPO SOIGSI, 2011. 687 p. (In Russian);
}

with different models of polylingual education, which together gives a tangible result.

It is also worth noting the fact that only in two regions, Tatarstan and Bashkortostan, their polylinguality is clearly indicated in the names of schools. There are currently two of them in the Republic of Tatarstan: the state autonomous educational institution Multilingual complex "Adymnar - the way to knowledge and consent" and the municipal autonomous educational institution Multilingual educational Complex "Adymnar - Alabuga" of the Yelabuga municipal district of the Republic of Tatarstan. Both educational institutions were opened in 2020 and are under the patronage of the Chairman of the Board of Trustees of the Republican Renaissance Foundation, the first President of Tatarstan, State Counselor of the Republic of Tatarstan M. Sh. Shaimiev. In the Republic of Bashkortostan, the opening of a network of polylingual multidisciplinary schools is one of the strategic directions of the socio-economic development of the Republic of Bashkortostan until 2024 being implemented in accordance with the Decree of the Head of the Republic of Bashkortostan dated September 23, 2019 No. UG-310. In 2020, 2021, four multilingual schools were opened (two in Ufa, one in Sterlitamak and one in Neftekamsk), in three of them, the native language is Bashkir, while in Neftekamsk, it is Tatar. Although there are no general education institutions in other regions that have the nominal status of polylingual, they represent schools that implement certain polylingual models: to a greater extent, in the Republics of North OssetiaAlania, Sakha (Yakutia), the Chechen Republic,

Skodtaev K. B. Russian-Ossetian, Ossetian-Russian school explanatory dictionary of mathematical terms. Vladi-kavkaz, OlimpGod, 2006. 379 p. (In Russian) 
to a lesser extent in the Kabardino-Balkarian Republic and in Chuvashia. The same can be noted with regard to preschool educational organizations: despite the fact that there are currently no institutions with an official polylingual status in the regions, some kindergartens have been specified for interaction with polylingual schools.

In all the regions, much attention is paid to developing and improving the educational and methodological kits (EMK), elaborating textbooks on different subject lines. Tatarstan has made the most progress in the latter direction: 89 textbooks on the Tatar language and literature are included into the federal list of textbooks, 24 teaching kits are used as a teaching aid, and 79 teaching materials translated into Tatar are used in the educational process for primary and basic general education. In 2021, applications were submitted for inclusion of 38 EMKs for primary general education into the federal list of textbooks.

If we consider the second indicator - the degree of proficiency in the native language of school students, we can note that, on the one hand, it largely depends on the regional institutional support of the language environment, on the other hand, it determines the models in the implementation of polylingual education, among which, within the framework of the analysis, we distinguished the following three ones:

- "a native language - the Russian language - a foreign language";

- "the Russian language - a native language - a foreign language";

- "the Russian language - a native language and a foreign language".

The first model of polylingual education, which can be schematically reflected as follows: "a native language - the Russian language - a foreign language", is aimed at students whose level of proficiency in their native language is higher than the level of proficiency in Russian. This model assumes that in the $1^{\text {st }}$ and $2^{\text {nd }}$ grades, instruction is conducted in the native language in all subjects, except for Russian and literary reading in Russian. It is important to note that the teaching of the Russian language is based on the methodology of teaching a non-native language. As a subject of study, a foreign language is added in the $2^{\text {nd }}$ grade and a foreign language teaching is mainly based on the native language of the students. In grades 3-4, the educational process becomes bilingual, which involves the introduction of teaching some subjects in Russian (normally, when introducing new material, explaining a new topic, the lesson is conducted in the native language, and when fixing and repeating the material - in Russian). The teaching of a foreign language is conducted with reference to the native and Russian languages. So, by the end of primary school, the level of Russian language proficiency is not inferior to the level of a native language proficiency, and students are prepared to study in Russian in basic school. Further, starting from the 5th grade, the educational process is mainly based on Russian. At the same time, in order to form students' general cultural competencies and develop their speech skills in their native language, a number of subjects (the native language and literature, fine arts, music, technology) continue to be taught in their native language. In addition, subjects or their sections of a local history character (history of the region, geography of the region) are taught in their native language. The teaching of a foreign language is conducted with reference only to the Russian language.

There is currently no implemented practice of teaching secondary general education students (grades 10-11) in the analyzed regions according to this polylingual model. However, the available practices presented in different regions consider 
the organization of the educational process in all subjects in Russian and foreign languages, leaving extracurricular time to the native language.

Thus, according to the given concept of polylingual education, at the primary level, the preference is given to the native language with a gradual alignment of positions with the Russian language by the end of primary school and the further predominance of the Russian language in basic and secondary schools with the teaching of a number of subjects in native and foreign languages.

\section{The second model of polylingual} education has become the most widespread in the national regions of Russia. It is focused on students whose native language proficiency is lower than their Russian language proficiency and, in principle, is at an elementary level. According to this model, all subjects in the $1^{\text {st }}$ and the $2^{\text {nd }}$ grades are taught in Russian. The exceptions are the subjects "the Native language" and "Literary reading in the native language", the teaching of the native language in which is carried out according to the methodology of teaching a non-native language. Elements of the native language are included in the process of teaching a number of subjects in grades 3 and 4 and continues in the basic school. A foreign language is studied in both primary and secondary schools as a subject.

Preliminary results of our pilot study showed that, for example, in the Republic of North Ossetia-Alania, there are no significant differences in the level of Russian language proficiency among the 4th grade students in schools realizing different models of polylingual education. It seems that the reason for this is the use of the Russian language in all spheres of a child's life. A comparison of the native language proficiency of 4th grade students demonstrates a big difference in the proficiency of the Ossetian language among schoolchildren studying in accordance with the first and the second models. Diagram 1 shows the results of testing of the 4th grade students in reading in the Ossetian language, writing in the Ossetian language, the maximum and minimum total scores in testing proficiency in the Ossetian language. The first research model is used in "Alan Gymnasium", the second - in "Gymnasium "Dialog" (both schools are located in Vladikavkaz).

Diagram 1

Results of testing of 4th grade students in reading and writing in the Ossetian language

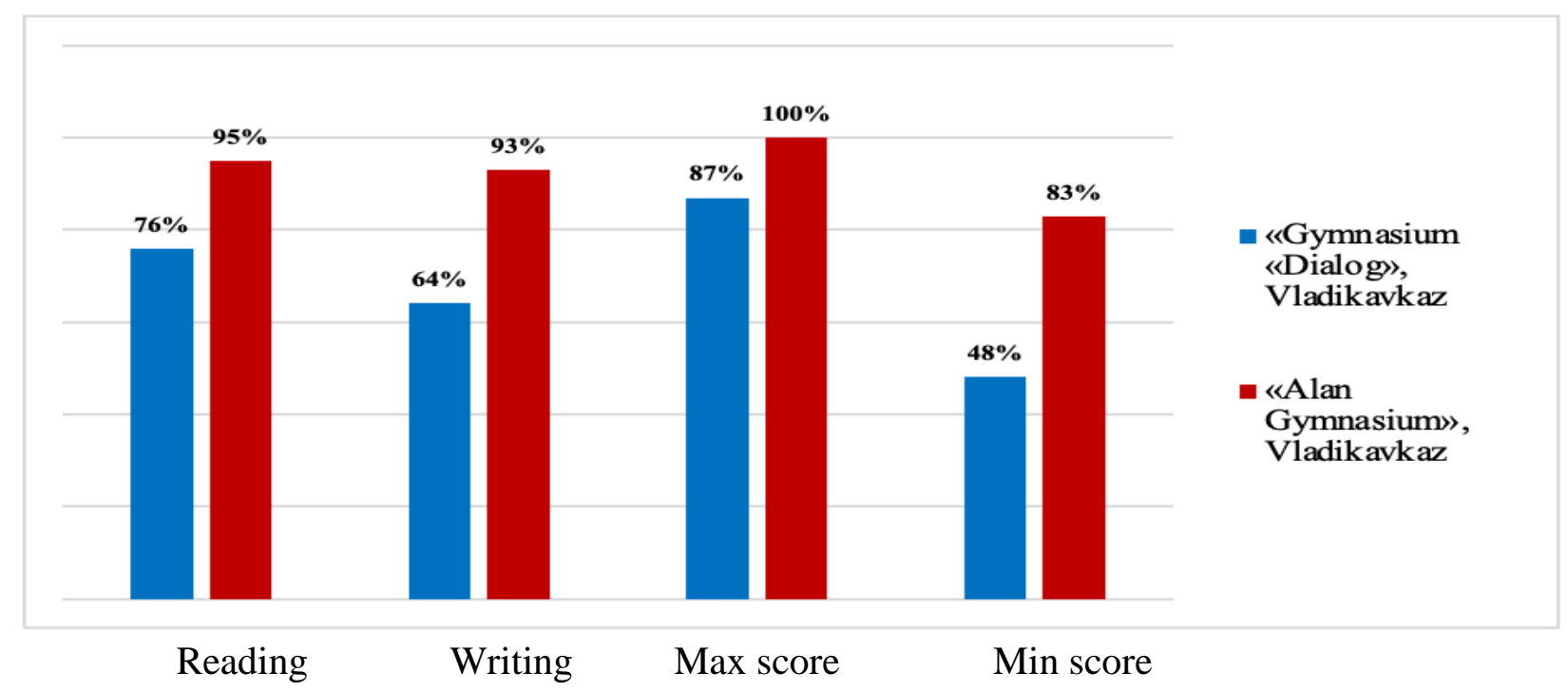


The test results show that the students representing "Alan Gymnasium" speak Ossetian at the level of $94 \%$, while the students of the "Gymnasium "Dialog" - around $70 \%$. At the same time, the difference in "reading" and "writing" among the representatives of the "Alan Gymnasium" is insignificant and is within the sampling error, whereas the difference among the students of "Gymnasium "Dialog" is more than $12 \%$. In addition, while the minimum score for the students of the first model is $83 \%$ with a 100 percent maximum score, the students of the second model have a maximum score closer to the minimum of "Alan Gymnasium", and the minimum score of the "Gymnasium "Dialog" does not exceed the 50 percent barrier. It is noteworthy that the level of reading in the native language is higher than the level of writing. This may be due to the productive, and therefore more complex nature of writing as a type of speech activity, as well as the fact that "Alan Gymnasium", in particular, pays great attention to the development of students' communicative competence in different languages, to their familiarization with national traditions and universal values. The same situation regarding the native language proficiency is observed in comparison of the first and the second models of polylingual education, for example, in the Chechen Republic, the Republic of Sakha and the Republic of Tatarstan.

The third polylingual model provides not only in-depth study of Russian, English and native languages, but also the teaching of other subjects in all the three languages. While in primary school this model repeats the second one to a greater extent, in basic school and especially in secondary school, subjects of mathematical profile (algebra, geometry) and of natural science profile (biology, geography) are taught in a foreign language. Despite the emphasis on studying and teaching in
Russian and English, these educational institutions also provide the study of the native language, literature in the native language and a second foreign language.

It can be said that the second and the third models "came out" of the Soviet system of schools with in-depth study of a foreign language and were successfully reworked taking into account the study of native languages. It was this fact that made it possible to conduct pilot studies in all the regions in 2021, for the ideas and principles of multicultural education are successfully implemented not only in educational institutions having the official status of a polylingual school, but also, as already mentioned, in a number of secondary schools with in-depth study of foreign languages, as well as schools with the teaching of several native languages.

\section{Discussion. Conclusions}

The experience of introducing polylingual educational models in the schools of the regions under study is generally assessed as positive by both teachers and high school students, so as it provides better acquisition of the material, especially in elementary school. At the same time, a number of problem areas are indicated, among which, first of all, are pedagogical personnel capable of conducting educational activities (especially in subject lines) equally qualitatively in Russian, in their native language, and in English. The problem is aggravated by the fact that multilingual schools are only at the initial stage of their development, higher education institutions do not train universal language and subject specialists, and retraining takes time and efforts. The second problematic issue is the edition of textbooks and teaching aids in native languages, which for some regions may not cause great financial difficulties (for example, Bashkortostan, Tatarstan), whereas for most 
regions, the issues of financing textbooks edition for polylingual schools, despite the deep methodological study of the issue (Chechnya, North Ossetia) or partial elaboration of methodological support (Sakha, KabardinoBalkaria, Chuvashia) are quite acute due to the deficit of regional budgets. Also, in some regions, experts highlight as problems the lack of teachers of the languages of the small peoples of the Far North (the Republic of Sakha), the lack of a system of advanced training for teachers in the framework of a polylingual model (KabardinoBalkaria), the situation with the grammatical component of school students' communicative competences in Russian and foreign languages, especially in remote rural settlements (Chechnya), the need for specific recommendations on relevant subjects, bi- or multilingual textbooks, manuals, control and measuring materials (Bashkortostan), the lack of scientific and methodological support for teachers of polylingual schools and the possibility of outflow of graduates of polylingual schools to other regions and countries (Tatarstan), the lack of a systematic approach to the implementation of polylingual education as such (the Republic of Chuvashia), the closure of the North Ossetian Pedagogical Institute.

In the course of research, the following scientific results were obtained:

1. Diagnostic materials have been developed for the organization of a comparative analysis of the practices of implementing multilingual education in the regions of the Russian Federation: checklists for assessing institutional support for the development of multilingual and multicultural education in the studied regions, checklists for the study of educational and methodological support of multilingual education in primary and basic general education organizations, questionnaires for students and teachers implementing language disciplines, tests in foreign and native languages.

2. Field studies of the practices of implementing multilingual education in the regions (Republic of Bashkortostan, KabardinoBalkar Republic, Republic of Sakha (Yakutia), Republic of North Ossetia-Alania, Republic of Tatarstan, Chechen Republic, Chuvash Republic) were conducted: collection and analysis of the material based on the application of the developed diagnostic device.

3. The main types of models of multilingual education implemented in the studied regions are determined. In particular, the models presented in the Republic of North Ossetia-Alania, the Republic of Tatarstan and the Republic of Sakha (Yakutia) are the most developed of them and have had experience of implementation for several years.

The conducted research has shown that there is no absolutely effective model in the Russian Federation for the development of polylingual training. Besides, for the development of the Concept of polylingual education, it is necessary to take into account sociodemographic, socio-cultural, ethno-confessional and religious aspects, which will allow textbook developers to better adapt the material for schoolchildren.

To achieve more precise conclusions, the research group of Bashkir State Pedagogical University named after M. Akmulla continues to work on studying the models of polylingual education being applied in the regions of Russia, in order to develop the Concept of polylingual education. 


\section{REFERENCES}

1. Sagitov S. T., Nasibullin R. T., Bakhtizin R. N. Priority ranking of social systems in managing the sociocultural processes: public opinion. Revista Inclusiones: Revista de Humanidades y Ciencias Sociales, 2020, vol. 7, pp. 697-710. ISSN 0719-4706 URL: https://revistainclusiones.org/index.php/inclu/article/view/1446

2. Sagitov S. T. The role of public opinion in the process of managing the sphere of culture. Sociology, 2017, no. 4, pp. 100-105. (In Russian) URL: https://www.elibrary.ru/item.asp?id=36983849\&

3. Kirss L., Saalik U., Leijen A., Pedaste M. School effectiveness in multilingual education: A review of success factors. Education Sciences, 2021, vol. 11 (5), pp. 193. DOI: https://doi.org/10.3390/educsci11050193

4. Van Avermaet P., Slembrouck S., Van Gorp K., Sierens S., Maryns K. (eds) The Multilingual Edge of Education. Palgrave Macmillan, 2018. 374 p. DOI: https://doi.org/10.1057/978-1-137-54856-6

5. Piccardo E., Germain-Rutherford A., Lawrence G. (eds) The Routledge Handbook of Plurilingual Language Education. New York, NY: Taylor and Francis, 2021. 534 p. DOI: https://doi.org/10.4324/9781351002783

6. Brisk M. E. (eds) Language in Writing Instruction: Enhancing Literacy in Grades 3-8. Milton: Taylor and Francis, 2020. 198 p. DOI: https://doi.org/10.4324/9780429397769

7. Hammer S., Viesca K. M., Commins N. L. (eds) Teaching Content and Language in the Multilingual Classroom: International Research on Policy, Perspectives, Preparation and Practice. Taylor and Francis, 2019. 218 p. DOI: https://doi.org/10.4324/9780429459443

8. Kourtis-Kazoullis V., Aravossitas T., Skourtou E., Trifonas P. P. (eds) Interdisciplinary Research Approaches to Multilingual Education, Taylor and Francis, 2018. 306 p. DOI: https://doi.org/10.4324/9781351170086

9. Curdt-Christiansen X. L., Wang W. Parents as agents of multilingual education: Family language planning in China». Language, Culture, and Curriculum, 2018, vol. 31 (3), pp. 235-254. DOI: https://doi.org/10.1080/07908318.2018.1504394

10. Breuer E. O., Lindgren E., Stavans A., Van Steendam E. (eds) Multilingual Literacy, 2021. 304 p. DOI: https://doi.org/10.21832/9781800410701

11. Gao X., Zheng Y. Multilingualism and higher education in Greater China. Journal of Multilingual and Multicultural Development, 2019, vol. 40 (7), pp. 555-561. DOI: https://doi.org/10.1080/01434632.2019.1571073

12. Duarte J., Günther-van der Meij M. A holistic model for multilingualism in education. E-JournALL, EuroAmerican Journal of Applied Linguistics and Languages, 2018, vol. 5 (2), pp. 24-43. DOI: https://doi.org/10.21283/2376905X.9.153

13. Wang L., Kirkpatrick A. Trilingual education in Hong Kong primary schools: An overview. Multilingual Education, 2015, vol. 5, pp. 3. DOI: https://doi.org/10.1186/s13616-015-0023-8

14. $\mathrm{Xu} \mathrm{H}$, Shan $\mathrm{Z}$. Teaching and learning multiple varieties of a foreign language for sustainable multilingual education. Sustainability, 2021, vol. 13 (14), pp. 8004. DOI: https://doi.org/10.3390/su13148004

15. Schwartz M. Preschool bilingual education agency in Interactions between children, teachers, and parents. Springer, 2018. 374 p. ISBN: 978-3-319-77228-8 DOI: https://doi.org/10.1007/978-3319-77228-8

16. Zhang L., Tsung L. Bilingual education and minority language maintenance in China. The Role of Schools in Saving the Yi Language. Springer, 2019. 165 p. ISBN: 978-3-030-03454-2 DOI: https://doi.org/10.1007/978-3-030-03454-2 
17. Teng M. F. Identity, Motivation, and Multilingual education in Asian contexts, 2020. 193 p. DOI: https://doi.org/10.5040/9781350099685

18. Hollebeke I., Struys E., Agirdag O. Can family language policy predict linguistic, socio-emotional and cognitive child and family outcomes? A systematic review. Journal of Multilingual and Multicultural Development, 2020. Latest Articles. DOI: https://doi.org/10.1080/01434632.2020.1858302

19. Paulsrud B., Zilliacus H., Ekberg L. Spaces for multilingual education: Language orientations in the national curricula of Sweden and Finland. International Multilingual Research Journal, 2020, vol. 14 (4), pp. 304-318. DOI: https://doi.org/10.1080/19313152.2020.1714158

20. Cenoz J., Leonet O., Gorter D. Developing cognate awareness through pedagogical translanguaging. International Journal of Bilingual Education and Bilingualism, 2021, Latest Articles, pp. 1-15. DOI: https://doi.org/10.1080/13670050.2021.1961675

21. Aronin L. Challenges of multilingual education: streamlining affordances through dominant language constellations. Stellenbosch Papers in Linguistics Plus, 2019, vol. 58, pp. 235-256. DOI: https://doi.org/10.5842/58-0-845

22. Bolton K. Language policy and planning in Hong Kong: Colonial and post-colonial perspectives. Applied Linguistic Review, 2011, vol. 2, pp. 51-74. DOI: https://doi.org/10.1515/9783110239331.51

23. Adinolfi L., Phyak P., Bhattacharya U. Multilingual Education in South Asia: At the Intersection of Policy and Practice. Taylor and Francis, 2022. 216 p. DOI: https://doi.org/10.4324/9781003158660

24. Gorter D., Cenoz J. Language education policy and multilingual assessment. Language and Education, 2016, vol. 31 (3), pp. 231-248. DOI: https://doi.org/10.1080/09500782.2016.1261892

25. Wang L. Trilingual education in Hong Kong secondary schools: A case study. Silk Road: A Journal of Eurasian Development, 2020, vol. 2 (1), pp. 18-34. DOI: https://doi.org/10.16997/srjed.10

Submitted: 19 November 2021 Accepted: 10 January 2022 Published: 28 February 2022

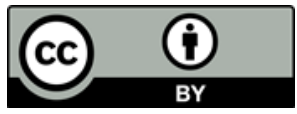

This is an open access article distributed under the Creative Commons Attribution License which permits unrestricted use, distribution, and reproduction in any medium, provided the original work is properly cited. (CC BY 4.0).

\section{The authors' stated contribution:}

Raisa Mingazitdinovna Iksanova

Contribution of the co-author: responsible executor of the research project, senior researcher; collection of empirical material of the presented research, writing the text of the article.

Zarima Rinatovna Kireeva

Contribution of the co-author: senior researcher; collection of empirical material of the presented research, writing the text of the article.

Eduard Irekovich Sattarov

Contribution of the co-author: junior researcher; data processing of empirical material and writing the text of the article. 
Salavat Talgatovich Sagitov

Contribution of the co-author: management of the research project; collection of empirical material of the presented research, data processing and writing the text of the article.

\section{Information about competitive interests:}

The authors claim that they do not have competitive interests.

\section{Information about the Authors}

\section{Raisa Mingazitdinovna Iksanova}

Candidate of Philological Sciences, Associate Professor, Head of the

Department,

Department of English,

Bashkir State Pedagogical University named after M. Akmulla,

October Revolution str., 3-a, 450008, Republic of Bashkortostan, Ufa, Russian Federation.

ORCID ID: https://orcid.org/0000-0002-4517-937X

E-mail: iks_raichka@mail.ru

\section{Zarima Rinatovna Kireeva}

Candidate of Pedagogical Sciences, Associate Professor,

Department of Methods of Teaching Foreign Languages and a Second Foreign Language,

Bashkir State Pedagogical University named after M. Akmulla,

October Revolution str., 3-a, 450008, Republic of Bashkortostan, Ufa, Russian Federation.

ORCID ID: https://orcid.org/0000-0002-5016-7365

E-mail: metodika-fr@yandex.ru

\section{Eduard Irekovich Sattarov}

Director,

Analytical Center,

Bashkir State Pedagogical University named after M. Akmulla,

October Revolution str., 3-a, 450008, Republic of Bashkortostan, Ufa, Russian Federation.

ORCID ID: https://orcid.org/0000-0002-4489-6369

E-mail: sattarov.eduard@mail.ru

\section{Salavat Talgatovich Sagitov}

Candidate of Sociological Sciences, Rector,

Bashkir State Pedagogical University named after M. Akmulla,

October Revolution str., 3-a, 450008, Republic of Bashkortostan, Ufa, Russian Federation.

ORCID ID: https://orcid.org/0000-0002-7211-1004

E-mail: salavatst@list.ru (Corresponding Author) 


\title{
Изучение практик внедрения полилингвальной модели поликультурного образования на территории Российской Федерации
}

\author{
Р. М. Иксанова ${ }^{1}$, 3. Р. Киреева ${ }^{1}$, Э. И. Саттаров ${ }^{1}$, С. Т. Сагитов ${ }^{1}$ \\ ${ }^{1}$ Башкирский государственный педагогический университет \\ имени Мифтахетдина Акмуллы, Уфа, Россия
}

Проблема и цель. В статье рассматриваются практики внедрения полилингвальной модели поликультурного образования на территории Российской Федерации. Как известно, Российская Федераџия многонаџиональная и лингвистически разнообразная страна. В России офиииальный язык - русский, 37 государственных языков в республиках Российской Федерации; более 15 языков с официальным статусом. Для ряда регионов страны модель полилингвального обучения крайне актуальна. Цель статьи - изучение практик внедрения полилингвальной модели поликультурного образования на территории Российской Федерачии, их сравнительный анализ.

Методология. В рамках исследования проводился анализ нормативных документов, регламентирующих прочессы поликультурного и полилингвального образования в Республике Северная Осетия - Алания, Кабардино-Балкарской Республике, Чеченской Республике, Республике Саха (Якутия), Республике Татарстан, Чувашской Республике, Республике Башкортостан (государственные программы, концепиии, положения и др.), организовывались круглье столы и беседы с научно-педагогическим сообществом регионов, изучались учебные планы образовательных организаций, программы и учебно-методические комплекты по языковым дисииплинам, реализуемым в СОО, посещались уроки, проводилось анкетирование и тестирование обучающихся начальной (4 класс) и основной школ (8 класс) по иностранным и родным языкам, анализировались результаты достижений обучающихся (результать Всероссийской олимпиады школьников по русскому и иностранным языкам, Всероссийских проверочных работ, государственной итоговой аттестации, единого государственного экзамена).

Результаты. Результаты заключаются в определении основных типов моделей полилингвального образования, реализуемых в исследуемых регионах. В частности, наиболее

Финансирование проекта: Исследование выполнено в рамках проекта государственного задания Министерства просвещения Российской Федерации № 073-03-2021-015/2 от 21.07.2021 г. на выполнение научно-исследовательской работы по теме «Сравнительный анализ практик внедрения полилингвальной модели поликультурного образования».

Библиографическая ссылка: Иксанова Р. М., Киреева 3. Р., Саттаров Э. И., Сагитов С. Т. Изучение практик внедрения полилингвальной модели поликультурного образования на территории Российской Федерации // Science for Education Today. - 2022. - Т. 12, № 1. - C. 125-149. DOI: http://dx.doi.org/10.15293/2658-6762.2201.06

曰 Автор для корреспонденции: Салават Талгатович Сагитов, salavatst@ list.ru

(C) Р. М. Иксанова, 3. Р. Киреева, Э. И. Саттаров, С. Т. Сагитов, 2022 


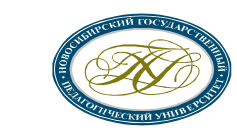

Science for Education Today

2022. Том 12. № 1 http://sciforedu.ru/

ISSN 2658-6762

разработанными из них и имеющими опыт внедрения в течение нескольких лет являются модели, представленные в Республике Северная Осетия - Алания, Республике Татарстан и Республике Саха (Якутия). Полученные результаты помогут достичь большего понимания специфики полилингвального образования в России, а само исследование способствует теоретическому вкладу в изучение полилингвального образования в цуелом.

Заключение. В заключении делается вывод, что в настоящее время в школах России нет согласованной модели внедрения полилингвального образования. Развитие полилингвальной модели поликультурного образования в первую очередь нацелено на сохранение и дальнейшее развитие родного языка в субъектах Российской Федераџии, что остается одной из важнейших задач не только решения узко этнокультурных вопросов, но и в контексте сохранения естественной поликультурной основы многонационального российского государства.

Ключевые слова: полилингвальное образование; полилингвальная модель; практика внедрения полилингвальной модели; поликультурная среда; сравнительный анализ практик внедрения полилингвальной модели; система образования; родной язык.

\section{СПИСОК ЛИТЕРАТУРЫ}

1. Sagitov S. T., Nasibullin R. T., Bakhtizin R. N. Priority ranking of social systems in managing the sociocultural processes: public opinion // Revista Inclusiones: Revista de Humanidades y Ciencias Sociales. - 2020. - Vol. 7. - P. 697-710. ISSN 0719-4706 URL: https://revistainclusiones.org/index.php/inclu/article/view/1446

2. Сагитов С. Т. Роль общественного мнения в процессе управления сферой культуры // Социология. - 2017. - №. 4. - C. 100-105. URL: https://www.elibrary.ru/item.asp?id=36983849\&

3. Kirss L., Saalik U., Leijen A., Pedaste M. School Effectiveness in Multilingual Education: A Review of Success Factors // Education Sciences. - 2021. - Vol. 11 (5). - P. 193. DOI: https://doi.org/10.3390/educsci11050193

4. Van Avermaet P., Slembrouck S., Van Gorp K., Sierens S., Maryns K. (eds) The Multilingual Edge of Education. - Palgrave Macmillan, 2018. - 374 p. DOI: https://doi.org/10.1057/978-1-137-54856-6

5. Piccardo E., Germain-Rutherford A., Lawrence G. (eds) The Routledge Handbook of Plurilingual Language Education. - New York, NY: Taylor and Francis, 2021. - 534 p. DOI: https://doi.org/10.4324/9781351002783

6. Brisk M. E. (eds) Language in Writing Instruction: Enhancing Literacy in Grades 3-8. Milton: Taylor and Francis, 2020. - 198 p. DOI: https://doi.org/10.4324/9780429397769

7. Hammer S., Viesca K. M., Commins N. L. (eds) Teaching Content and Language in the Multilingual Classroom: International Research on Policy, Perspectives, Preparation and Practice. - Taylor and Francis, 2019. - 218 p. DOI: https://doi.org/10.4324/9780429459443

8. Kourtis-Kazoullis V., Aravossitas T., Skourtou E., Trifonas P. P. (eds) Interdisciplinary Research Approaches to Multilingual Education. - Taylor and Francis, 2018. - 306 p. DOI: https://doi.org/10.4324/9781351170086 


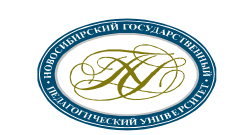

Science for Education Today

9. Curdt-Christiansen X. L., Wang W. Parents as Agents of Multilingual Education: Family Language Planning in China // Language, culture, and curriculum. - 2018. - Vol. 31 (3). P. 235-254. DOI: https://doi.org/10.1080/07908318.2018.1504394

10. Breuer E. O., Lindgren E., Stavans A., Van Steendam E. (eds.) Multilingual literacy, 2021. - 304 p. DOI: https://doi.org/10.21832/9781800410701

11. Gao X., Zheng Y. Multilingualism and higher education in Greater China // Journal of Multilingual and Multicultural Development. - 2019. - Vol. 40 (7). - P. 555-561. DOI: https://doi.org/10.1080/01434632.2019.1571073

12. Duarte J., Günther-van der Meij M. A holistic model for multilingualism in education // EJournALL, EuroAmerican Journal of Applied Linguistics and Languages. - 2018. Vol. 5 (2). - P. 24-43. DOI: https://doi.org/10.21283/2376905X.9.153

13. Wang L., Kirkpatrick A. Trilingual Education in Hong Kong Primary Schools: an overview // Multilingual Education. - 2015. - Vol. 5. - P. 3. DOI: https://doi.org/10.1186/s13616-015-0023-8

14. Xu H, Shan Z. Teaching and Learning Multiple Varieties of a Foreign Language for Sustainable Multilingual Education // Sustainability. - 2021. - Vol. 13 (14). - P. 8004. DOI: https://doi.org/10.3390/su13148004

15. Schwartz M. Preschool bilingual education agency in Interactions between children, teachers, and parents. - Springer, 2018. - 374 p. ISBN: 978-3-319-77228-8 DOI: https://doi.org/10.1007/978-3-319-77228-8

16. Zhang L., Tsung L. Bilingual education and minority language maintenance in China. The Role of Schools in Saving the Yi Language. - Springer, 2019. - 165 p. ISBN: 978-3-03003454-2 DOI: https://doi.org/10.1007/978-3-030-03454-2

17. Teng M. F. Identity, Motivation, and Multilingual education in Asian contexts, 2020. 193 p. DOI: https://doi.org/10.5040/9781350099685

18. Hollebeke I., Struys E., Agirdag O. Can family language policy predict linguistic, socioemotional and cognitive child and family outcomes? A systematic review // Journal of Multilingual and Multicultural Development. - 2020. DOI: https://doi.org/10.1080/01434632.2020.1858302

19. Paulsrud B., Zilliacus H., Ekberg L. Spaces for multilingual education: language orientations in the national curricula of Sweden and Finland // International Multilingual Research Journal. - 2020. - Vol. 14 (4). $\quad$ - $\quad$ P. 304-318. DOI: https://doi.org/10.1080/19313152.2020.1714158

20. Cenoz J., Leonet O., Gorter D. Developing cognate awareness through pedagogical translanguaging // International Journal of Bilingual Education and Bilingualism. - 2021. P. 1-15. DOI: https://doi.org/10.1080/13670050.2021.1961675

21. Aronin L. Challenges of multilingual education: streamlining affordances through Dominant Language Constellations // Stellenbosch Papers in Linguistics Plus. - 2019. Vol. 58. - P. 235-256. DOI: https://doi.org/10.5842/58-0-845

22. Bolton K. Language policy and planning in Hong Kong: Colonial and post-colonial perspectives // Applied linguistic review. - 2011. - Vol. 2. - P. 51-74. DOI: https://doi.org/10.1515/9783110239331.51 


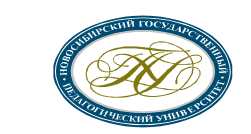

Science for Education Today

2022. Том 12. № 1 http://sciforedu.ru/

ISSN 2658-6762

23. Adinolfi L., Phyak P., Bhattacharya U. Multilingual Education in South Asia: At the Intersection of Policy and Practice. - Taylor and Francis, 2022. - 216 p. DOI: https://doi.org/10.4324/9781003158660

24. Gorter D., Cenoz J. Language education policy and multilingual assessment // Language and Education. - 2016. - Vol. 31 (3). - P. 231-248. DOI: https://doi.org/10.1080/09500782.2016.1261892

25. Wang L. Trilingual Education in Hong Kong Secondary Schools: A Case Study // Silk Road: A Journal of Eurasian Development. - 2020. - Vol. 2 (1). - P. 18-34. DOI: https://doi.org/10.16997/srjed.10

Поступила: 19 Ноября 2021 Принята: 10 января 2022 Опубликована: 28 февраля 2022

\section{Заявленный вклад авторов:}

Иксанова Раиса Мингазитдиновна: ответственный исполнитель научно-исследовательского проекта, старший научный сотрудник; сбор эмпирического материала представленного исследования, написание текста статьи.

Киреева Зарима Ренатовна: старший научный сотрудник; сбор эмпирического материала представленного исследования, написание текста статьи.

Саттаров Эдуард Ирекович: младший научный сотрудник; обработка данных эмпирического материала и написание текста статьи.

Сагитов Салават Талгатович: руководство научно-исследовательским проектом; сбор эмпирического материала представленного исследования, обработка данных и написание текста статьи.

\section{Информация о конфликте интересов:}

Авторы заявляют об отсутствии конфликта интересов.

\section{Информация об авторах}

\section{Иксанова Раиса Мингазитдиновна}

кандидат филологических наук, доцент, заведующий кафедрой, кафедра английского языка,

Башкирский государственный педагогический университет имени Мифтахетдина Акмуллы,

ул. Октябрьской революции, 3-a, 450008, Республика Башкортостан, Уфа, Российская Федерация.

ORCID ID: https://orcid.org/0000-0002-4517-937X

E-mail: iks_raichka@mail.ru 


\section{Киреева Зарима Ренатовна}

кандидат педагогических наук, доцент, кафедра методики преподавания иностранных языков и второго иностранного языка, Башкирский государственный педагогический университет имени Мифтахетдина Акмуллы, ул. Октябрьской революции, 3-a, 450008, Республика Башкортостан, Уфа, Российская Федерация.

ORCID ID: https://orcid.org/0000-0002-5016-7365

E-mail: metodika-fr@yandex.ru

\section{Саттаров Эдуард Ирекович}

директор, аналитический центр,

Башкирский государственный педагогический университет имени Мифтахетдина Акмуллы,

ул. Октябрьской революции, 3-a, 450008, Республика Башкортостан, Уфа, Российская Федерация.

ORCID ID: https://orcid.org/0000-0002-4489-6369

E-mail: sattarov.eduard@mail.ru

\section{Сагитов Салават Талгатович}

кандидат социологических наук, ректор,

Башкирский государственный педагогический университет имени Мифтахетдина Акмуллы,

ул. Октябрьской революции, 3-a, 450008, Республика Башкортостан, Уфа, Российская Федерация.

ORCID ID: https://orcid.org/0000-0002-7211-1004

E-mail: salavatst@list.ru 